Rok XIV (2019) | 2 (28) | s. 305-317

https://doi.org/10.12797/LV.14.2019.28.21

Łukasz Wnuk (๑)

Uniwersytet Warszawski, Warszawa

I.wnuk@student.uw.edu.pl

\title{
OBSERWATOR I JEGO POZYCJA W OPOWIADANIU TADEUSZA BOROWSKIEGO ODWIEDZINY
}

Słowa klucze: Tadeusz Borowski, opowiadanie, Ronald Langacker, subiektyfikacja, scena, punkt widzenia

Keywords: Tadeusz Borowski, short-story, Ronald Langacker, subjectification, scene, vantage point

\section{Cel artykułu}

Opatrzone przez autora tytułem Odwiedziny opowiadanie, powstałe niedługo po zakończeniu II wojny światowej i powrocie Tadeusza Borowskiego do Polski, nie doczekało się recepcji porównywalnej z tą, jaką miało Pożegnanie z Marią. Tę samą uwagę można odnieść także do całego tomu Kamienny świat, zamykanego przez Odwiedziny. Z kolei w obrębie językoznawczych badań literackich Borowski zasadniczo się nie pojawia.

Celem moich badań było pójście za sugestią Sławomira Buryły (2004: 246), dostrzegającego konieczność „wyjścia poza dotychczasowy język, jakim zwykło się mówić o tej prozie". Rolę nowego sposobu analizowania literackiego dorobku Borowskiego przyjąć może z powodzeniem aparat metodologiczny związany z językoznawstwem kognitywnym (a szczególnie z wybranymi założeniami gramatyki Ronalda Langackera), który pozwala na znacznie bardziej drobiazgowy opis zabiegów wykorzystanych przez mówiącego w opowiadaniu. 
Ujęcie kognitywistyczne nie było dotychczas wykorzystywane $\mathrm{w}$ badaniach twórczości autora Pożegnania $z$ Marią. Cennym jego uzupełnieniem jest praca Petera Stockwella (2006), prezentująca szerokie możliwości interpretowania tekstu literackiego w oparciu o istniejące teorie językoznawcze. Wyrażone przez autora przekonanie o konieczności „zwrócenia uwagi na okoliczności użycia jako zasadniczego elementu analizy językoznawczej”, a także potrzebie „rozpatrywania psychologicznych i społecznych okoliczności stosowania języka" przy tworzeniu nowych konstruktów pojęciowych w obrębie gramatyki kognitywnej (ibid.: 86-87) umożliwia wypełnienie rozziewu między teorią Langackera a czysto literacką wypowiedzią Borowskiego.

Ustęp następujący po niniejszym poświęcony jest wybranym tezom interpretacyjnym stawianym dotychczas przy okazji badań nad literackim dorobkiem Borowskiego. Przywołane opinie pochodzą przede wszystkim z opracowań biograficznych lub przekrojowych ujęć jego twórczości. Pełnią funkcję horyzontu poznawczego, na którego tle możliwe będzie usytuowanie zgromadzonych wniosków. Niektóre z nich kontrastować będą z wcześniejszymi interpretacjami.

Kolejna część obejmuje właściwą analizę opowiadania poprzedzoną prezentacją jego pełnego tekstu. Rolę głównego komponentu teoretycznego odgrywa gramatyka kognitywna Langackera, ze szczególnym uwzględnieniem pojęć konceptualizacji, bieżącej przestrzeni dyskursu oraz trajektora i landmarka. Uznając wypowiedź bohatera za monolog wewnętrzny, można ją również opisać jako $z$ darzenie użycia mowy, z wykorzystaniem pojęć egocentrycznego i optymalnego układu ogladu, a także mechanizmów przemieszczenia - subiektyfikacji oraz obiektyfikacji.

Powyższe założenia mogą z powodzeniem pełnić funkcję narzędzi odpowiednich do analizy i opisu Odwiedzin jako zarazem odrębnego tekstu literackiego powiązanego na kilku poziomach $\mathrm{z}$ charakterystycznymi, biograficznie i historycznie uwarunkowanymi cechami twórczości konkretnego pisarza, jak i wypowiedzi językowej obserwatora, przedstawiającego własną konceptualizację wydarzeń z przeszłości, które mają dlań charakter osobistego doświadczenia. Odwołanie do wymienionych elementów gramatyki kognitywnej pozwala usytuować wypowiedź literacką w przestrzeni zabiegów językowych towarzyszących standardowej komunikacji. Dopiero wówczas w pełni widoczna staje się drobiazgowo zaplanowana (wbrew niektórym sugestiom badaczy) i wielopoziomowa kompozycja utworu, pełniejszy wydźwięk zyskuje ponadto jego zakończenie.

Konsekwencją takiego porządku opracowania może być wzajemne przenikanie się pojęć, szczególnie tych związanych z mówiącym oraz budową poszczególnych obrazów i scen w utworze. Ich opis, uwzględniający najpierw podział na elementy pierwszo- i drugoplanowe, następnie zaś przemieszczanie obserwatora w obrębie opisywanej sceny, prowadzić będzie do poszerzenia dotychczasowych interpretacji Odwiedzin. 


\section{Echo wielkiej prozy obozowej - o dotychczasowym odbiorze twórczości Borowskiego}

Do prozy T. Borowskiego przylgnęły stosunkowo trwale uproszczone refleksje interpretacyjne, najczęściej kojarzące jego technikę pisarską z właściwą ówczesnej literaturze amerykańskiej narracją behawiorystyczną. Taki kierunek interpretacji podsuwa czytelnikom sam autor, przyznając się do czerpania z tej konwencji w jednym ze swych listów ${ }^{1}$. Lektura opracowań poświęconych zarówno biografii pisarza, jak i charakterystycznym cechom jego utworów pozwala zauważyć, że ze spostrzeżenia Borowskiego uczyniono punkt wyjścia do odczytywania dwóch stworzonych przez niego zbiorów: Pożegnanie $z$ Mariq oraz Kamienny świat, a także poszczególnych opowiadań.

Omawiany tutaj utwór wszedł w skład drugiego z tomów, powstał zaś w okresie jednego z poważniejszych kryzysów trapiących Borowskiego po opuszczeniu obozu przejściowego, gdy wojna dobiegła już końca ${ }^{2}$. Jak podaje jeden z jego biografów, Tadeusz Drewnowski (1992: 404), wtedy też podjął pisarz pierwszą próbę samobójczą. Przywołane okoliczności sugerowałyby, że napisane opowiadanie powinno zawierać co najmniej pojedyncze odniesienia do samoświadomości piszącego.

Hipotezę potwierdza fakt, iż owa zdolność oceny własnej wewnętrznej kondycji stanowi u Borowskiego dość często centralny element świata przedstawionego. Same obserwacje nierzadko wzbogacał Borowski o perspektywę aksjologiczną (Mencwel 1971: 150, 153). Inny z badaczy stwierdził, że w kontekście tej prozy można mówić wręcz o „moralistycznej pasji, która narzuca się odbiorcy z rzadko spotykaną siłą" (Werner 1971: 152). Pojawiła się także sugestia, iż pisarz buduje konsekwentny i silny obraz poszukującego człowieka i artysty (Drewnowski 1992: 389).

W obrębie prac poświęconych twórczości autora Kamiennego świata pojawiają się opinie $\mathrm{w}$ sposób zdecydowany odbierające podmiotowi mówiącemu opowiadań osobowość i indywidualność. W cytowanym opracowaniu Andrzeja Wernera zawarte zostało stwierdzenie, że technika prozatorska Borowskiego oparta jest na „całkowitym braku introspekcji, monologów wewnętrznych” oraz rejestrowaniu wyłącznie cudzych zachowań lub gestów (Werner 1971: 149). W pracach późniejszych badacz dostrzegał także dysproporcję między jakością literacką pierwszego i drugiego tomu opowiadań - powstałe po Pożegnaniu z Marią opowiadania wchodzące

1 Por. „Jak przeczytasz, to odeślij i napisz, co o tym sądzisz. Jakie są możliwości polskiej short story?" (Borowski 2001: 227).

2 W korespondencji Borowskiego znaleźć można m.in. następujące stwierdzenia: „Doszedłem do wniosku, że przez ostatnie lata nie pomnożyłem się absolutnie na tzw. duchu ani nie dojrzałem, że to, co mam w sobie z tzw. dobra, zostało jeszcze z czasów Skaryszewskiej, że moje instynkty wypaczyły się zabawnie. Okazało się również, że niewiele umiem. Wiele moich autosugestii okazało się bezpodstawnymi ku niemałej mojej uciesze. Tyle dotychczas dowiedziałem się o sobie. Jestem trochę zdziwiony i rozweselony. [...] Przegrałem w bardzo piękną grę. Wydaje mi się, że taką grę gra się tylko raz" (ibid.: 153). 
w skład Kamiennego świata miałyby być ,już tylko echem wielkiej prozy obozowej, w niektórych tonach nawet echem fałszywym" (Werner 1997: XIX).

Poprzez analizę tego, w jaki sposób zmienia się w Odwiedzinach pozycja bohatera-narratora względem opisywanych wydarzeń, podjąć można próbę dokładniejszego opisu jego wypowiedzi. Jej zauważalna i bardzo rygorystyczna kompozycja, zdominowana przez powtórzenia (szczególnie czasownika percepcyjnego widzieć w pierwszej osobie i czasie przeszłym) oraz regularność składniową, nie wyklucza w opowiadaniu łączenia perspektyw czasowych (zdarzeń i procesów, przeszłości, teraźniejszości i przyszłości).

Koncentracja na pomijanych dotąd aspektach skomplikowanych relacji między autorem, narratorem i bohaterem analizowanego opowiadania oraz ukształtowania wypowiedzi umożliwia stworzenie opisu szerokiego i wieloaspektowego, przekraczającego wielokrotnie objętość utworu, zamkniętego w około pięciuset wyrazach. Wyznaczony zakres jest tego opisu jedynie wycinkiem, przygotowanym świadomie na potrzeby niniejszej publikacji.

Możliwe wydaje się także odniesienie do obecnych w dotychczasowych badaniach, chociażby Dariusza Kuleszy (2006), twierdzeń, jakoby Odwiedziny stanowiły przykład utworu przede wszystkim dyskursywnego i polemicznego, którego celem jest atak wymierzony w krytykę, bowiem „ich estetyczna dyscyplina była zbyt sztywna, by mogła uchodzić za dyskretną" (ibid.: 285, 331). Zapytać można, na ile prawdziwa byłaby teza, iż nadużyciem byłoby (w ślad za Aleksandrem Watem) uznawanie opowiadań z tomu Kamienny świat za maksymalnie skondensowane powieści (Werner 1997: CVI). Rozważyć należy ponadto obecne w ostatnim z przywołanych źródeł pytanie, czy rzeczywiście można uznać ów zbiór za największe osiągnięcie polskiej prozy powojennej.

\section{Opowiadanie Tadeusza Borowskiego Odwiedziny w perspektywie koncepcji Ronalda Langackera}

\subsection{Pełny tekst utworu}

Szedłem nocą, piąty w szeregu. Brązowy płomień palonych ludzi chwiał się w środku fioletowego nieba.

W tej łagodnej ciemności miałem oczy szeroko otwarte i chociaż krew z przebitego bagnetem uda obejmowała mi ciało ciepłem, które przy każdym kroku potęgowało się aż do bólu, a z tyłu przez gęsty, skwapliwy tupot męskich nóg wyczuwałem drobny, lękliwy krok kobiet (wśród nich szła również dziewczyna, która kiedyś należała do mnie) - to jednak nie potrafię powtórzyć z tej nocy nic prócz tego, co widziałem, szeroko otwierając oczy.

Widziałem więc w tę noc, jak półnagi, parujący potem człowiek, wypadłszy na żwir rampy obozowej z bydlęcego wagonu, w którym nie było już powietrza, zachłys- 
nął się głęboko rześkim, chłodnym mrokiem, zatoczył się ku innemu człowiekowi i objąwszy go kurczowo ramieniem, począł wmawiać w niego nieprzytomnie: „bracie, bracie..."

Jeszcze inny człowiek ( $\mathrm{w}$ walce o powietrze przyduszono go $\mathrm{w}$ wagonie, przy szparze), leżąc w szopie na kupie dymiących ciał, kopnął nagle z całej siły schylonego nad nim złodzieja, który ściągał mu z nogi niepotrzebny już przecież umarłemu prawie nie używany, chromowy oficerski but.

Przez wiele dni potem widziałem, jak mężczyźni płakali nad kilofem, łopatą i przy lorze. Jak dźwigali szyny, worki z cementem, betonowe słupy na ogrodzenie, jak równali pieczołowicie ziemię, głaskali szuflami ściany rowów, wznosili baraki, wieże strażnicze i krematoria. Jak zżerały ich świerzb, flegmona, tyfus i głód. Widziałem innych, którzy kolekcjonowali brylanty, zegarki oraz złoto i skrzętnie chowali je w ziemi. Jeszcze inni ze snobizmu starali się zabić jak najwięcej ludzi i posiąść możliwie wiele kobiet.

Aha, widziałem także kobiety, które nosiły belki, pchały wozy i taczki oraz budowały tamy przy stawach. Także takie, które oddawały się za kawałek chleba. Takie, które stać było na kupno kochanka - za jedwabne koszule, za złoto i za biżuterię zrabowaną ludziom umarłym. Widziałem także dziewczynę (która kiedyś należała do mnie) pokrytą wrzodami i łysą, ale to już jest moja prywatna sprawa.

Ci wszyscy zaś, którzy z powodu flegmon, świerzbu i tyfusu, a także dlatego, że byli zbyt chudzi, szli do komory gazowej, prosili pielęgniarzy (ładujących ich na krematoryjne auta), aby patrzyli i pamiętali. I aby powiedzieli prawdę o człowieku - tym, którzy jej nie zaznali.

Właśnie spoglądam przez oplecione dzikim winem okno, za którym jest wypalony aż po niebo dom, dalej zwalisko klasycznej bramy z ocalałą amforą na kolumnie, banalne, pachnące i kwitnące drzewo lipowe oraz niebo zbiegające chmurami ku widnokręgowi ruin po drugiej stronie migotliwej rzeki.

Siedzę w cudzym pokoju wśród nie swoich książek i pisząc, że widziałem niebo, mężczyzn i kobiety, myślę uporczywie, iż tylko siebie nie mogłem zobaczyć. Pewien młody symbolistyczno-realistyczny poeta opowiada o mnie z kostycznym lekceważeniem, że mam obozowy kompleks. Za chwilę odłożę pióro i tęskniąc do ludzi, których wtedy widziałem, będę się zastanawiał, dokąd dziś pójść w odwiedziny: czy do przyduszonego człowieka w oficerkach, obecnie inżyniera elektrowni miejskiej, czy też do właściciela doskonale prosperującego baru, który kiedyś szeptał mi: „bracie, bracie..."

Innych odwiedzają ci, którzy grzebiąc w zmieszanych z ziemią, przegniłych ludzkich popiołach, pilnie szukają w nich zagubionego złota ${ }^{3}$.

3 Tekst opowiadania oraz wszystkie wykorzystane cytaty pochodzą z wydania Borowski 1997. 


\subsection{Konstrukcja scen w Odwiedzinach}

Pierwsze zdanie opowiadania pełni funkcję precyzyjnego wprowadzenia, informuje także o perspektywie oglądu konstruowanej sceny. Pozwala odbiorcy na wychwycenie komponentów symbolicznych, takich jak dynamika oraz uczestnictwo mówiącego - „szedłem”, pora - „noc” wraz z powiązanymi z nią kulturowymi implikacjami, spośród których należałoby wskazać przede wszystkim niepokój, zagubienie i zło. Ostatnim komponentem jest obecność większej grupy, w której obrębie tworzący scenę nie odgrywa żadnej szczególnej roli - ma jedynie określone miejsce w szeregu więźniów.

Informacja na temat przyjętej w opowiadaniu perspektywy jest zarazem wskazaniem centrum deiktycznego utworu - w pierwszym akapicie mówiący jawi się jako wyłączny dysponent wiedzy o doświadczeniu, a także powiązanych z nim relacjach czasowych i przestrzennych. Nie byłaby to sytuacja wyjątkowa, biorąc pod uwage obecne w dotychczasowych kognitywnych badaniach języka obserwacje prowadzące do wniosku, iż prototypowe kategorie deiktyczne w mowie opierają się na mówiącym, miejscu i czasie wypowiedzi (Stockwell 2006: 64).

Posługując się wyrażeniami deiktycznymi różnego typu ${ }^{4}$, autor wciela obserwatora w rolę trajektora ${ }^{5}$. Landmarkiem ${ }^{6}$ sceny czyni brązowy płomień, który chwieje się na tle fioletowego nieba. Obie barwy posiadają swoje prototypowe skojarzenia $-\mathrm{z}$ jednej strony smutek i nieczystość, z drugiej zaś żałoba (Tokarski 2004: 167, 185-186) ${ }^{7}$. Mówiący zauważa obecność tego elementu kompozycyjnego w kolejnym akapicie, gdy zderza ze sobą w wypowiedzi odmienne doznania percepcyjne.

Stwierdza wówczas, że choć czuje własny ból, będący skutkiem fizycznych obrażeń, a także „lękliwy krok kobiet” (metaforycznie również powiązany z ich negatywnymi odczuciami), w jego doświadczeniu rolę dominującą odgrywają doznania

4 Spośród tych wskazanych przez Stockwella (2006: 68) wspomnieć należy zwłaszcza o deiksach czasowych i percepcyjnych.

5 Uproszczoną i sfunkcjonalizowaną definicję terminu przedstawił Stockwell (ibid.: 22): „Figurę w schemacie wyobrażeniowym nazywamy trajektorem, a element, z którym figura wchodzi w relację, nazywamy landmarkiem. Trajektor pokonujący jakąś drogę względem landmarka - to ogólne elementy schematów wyobrażeniowych, reprezentujące abstrakcyjną strukturę pojęciową, która jest podłożem wszelkich tekstowych zastosowań danego schematu". Badacz zauważa również, że prototypowy podmiot przyjmuje w zdaniu zazwyczaj pozycję figury lub trajektora (ibid.: 89).

6 Pojęcie to Langacker tłumaczy koniecznością wyodrębniania różnych poziomów wyróżnienia dla danych wyrażeń relacyjnych, w których obrębie „zazwyczaj jeden uczestnik stanowi ognisko prymarne jako jednostka lokalizowana, oceniana lub w inny sposób opisywana. [...] Oprócz niego często występuje sekundarny uczestnik relacji, nazywany landmarkiem" (Langacker 2009: 156).

7 „Składowymi dla fioletu są chromatyczne kolory czerwony i niebieski oraz dodatek czerni, która sprawia, że kolor ten postrzegany jest jako najciemniejsza wśród barw chromatycznych" (Tokarski 2004: 185-186). 
wizualne - „to, co widziałem, szeroko otwierając oczy”. Koncentrując się na tym, co widzi, zacznie usuwać się sprzed oczu czytelnika, ponownie umieszczając siebie samego na pierwszym planie dopiero w pierwszym zdaniu drugiej części opowiadania, na które składają się jego ostatnie akapity.

Podział na trajektor i landmark nie musi wiązać się z dynamiką lub statycznością poszczególnych komponentów sceny, jednak w wypadku Odwiedzin najczęściej to ruch będzie przykuwał uwagę obserwatora, co jest wynikiem zorganizowania wypowiedzi wokół czynności. Można przyjąć, że w tle poszczególnych scen utworu nieustannie znajduje się w jego pierwszej części marszowy krok bohatera-narratora, wprowadzony już w pierwszym zdaniu.

Podział opowiadania wynika z zastosowanych perspektyw czasowych - najpierw jest to przeszłość, następnie zaś - teraźniejszość, zasygnalizowana na początku ostatnich trzech akapitów słowem „właśnie”, wiążąca się z przyszłością. Zorganizowanie pierwszej części Odwiedzin wokół ruchu uznać należy za zabieg zarówno dopuszczalny, jak i zrozumiały, co Langacker w kontekście domen poznawczych i ich konstrukcji uzasadnia następującymi słowami:

Ani trajektor nie musi być obiektem w ruchu, ani obiekt w ruchu nie musi być trajektorem. Trajektor i landmark są definiowane $w$ kategoriach prymarnego i sekundarnego wyróżnienia, a nie pełnionej roli semantycznej czy treści pojęciowej. A zatem pojęcia te znajdują zastosowanie w każdej domenie poznawczej, nie tylko w domenie przestrzeni (Langacker 2009: 107).

Po raz drugi występuje w opowiadaniu odwołanie do nocy, tym razem nie konceptualizowanej (jak poprzednio) jako punkt, na którego tle przemieszcza się mówiący, lecz jako wycinek czasu, będący tłem wszystkich kolejnych scen konstruowanych przez bohatera-narratora. Chęć „powtórzenia z tej nocy” zostaje wówczas wyrażona dosłownie, należy także zakładać, że narrator odwołuje się tu do kategoryzowania i strukturyzowania doświadczenia w pamięci.

W toku wypowiedzi zaznacza się przechodzenie przez mówiącego na coraz wyższy poziom ogólności - od szczegółowego opisu kolejnych elementów kontekstu ku przywoływaniu ich jako części procesu rozłożonego w czasie. Do pierwszego zbioru przynależy objęcie „innego człowieka” przez więźnia wypadającego na rampę z bydlęcego wagonu oraz cios wymierzony niedoszłemu złodziejowi chromowanych oficerek przez człowieka leżącego na stosie ciał. Do drugiego - wyliczenie czynności wykonywanych przez więźniów obojga płci.

Obserwator przywołuje sceny z udziałem mężczyzn („płakali nad kilofem, łopatą i przy lorze”, „dźwigali szyny, worki z cementem, betonowe słupy na ogrodzenie”, "równali pieczołowicie ziemię, głaskali szuflami ściany rowów, wznosili baraki, wieże strażnicze i krematoria”), a następnie te z udziałem kobiet („nosiły belki, pchały wozy i taczki oraz budowały tamy przy stawach"). 
Bieżąca przestrzeń dyskursu ${ }^{8}$ jest konstruowana przez nadawcę wypowiedzi za pomocą równomiernego nadbudowywania kolejnych elementów, powiązanych kompozycyjnie za pomocą czasownika percepcyjnego widzieć, organizującego całą retrospekcję. W wieńczącej ją scenie ładowania chorych na pokład aut jadących do krematorium zastosowany został czasownik patrzeć, różniący się jednakże pod względem stopnia zaangażowania podmiotu - nie implikuje on tak dużej aktywności poznawczej ani świadomości.

Samo pojęcie przestrzeni dyskursu prymarnie odnosi się do interakcji między mówiącym a słuchającym, podczas której obie strony współtworzą podstawę konwersacji, modyfikując ją za pomocą każdej następującej po sobie wypowiedzi przy wykorzystaniu odniesień do struktur informacji już wprowadzonych (ibid.: 90-91). W opowiadaniu Borowskiego odnaleźć można mechanizm bardzo podobny, kolejne doświadczenia są uzupełniane obrazami zapamiętanymi przez obserwatora.

Pozostała część wypowiedzi skontrastowana jest z poprzednią nie tylko za sprawą perspektywy czasowej (przeszłość i wspomnienia ustępują miejsca teraźniejszości), lecz także miejsca. Nie jest nim już obóz koncentracyjny, a „cudzy pokój”, w którym bohater-narrator czuje się opuszczony, otoczony przez przedmioty, których główną cechą ma być obcość, brak przynależności do niego samego.

W zestawieniu z wcześniejszym wspomnieniem obraz „Zwaliska klasycznej bramy z ocalałą amforą na kolumnie" jest mniej dosłowny, a przez to odmienny stylistycznie. Nadal ma jednak ścisły związek z doświadczeniami mówiącego, być może także z jego sytuacją po zakończeniu wojny. Swoje teraźniejsze położenie były więzień opisuje stwierdzeniem „pisząc, że widziałem niebo, mężczyzn i kobiety, myślę uporczywie, iż tylko siebie nie mogłem zobaczyć”, wykorzystującym relację aspektową między dwoma czasownikami percepcyjnymi widzieć i zobaczyć.

Poprzez ich zestawienie mówiący sygnalizuje, jakie znaczenie ma pozycja, z której obserwuje scenę - nie tylko decyduje o sposobie, w jaki utrwalone zostanie doświadczenie, lecz także determinuje jego wpływ na tożsamość doświadczającego. Kwestią otwartą pozostaje pytanie, czy niezależnie od przyjętej perspektywy narrator ma szansę na to, by skutecznie obserwować samego siebie.

Ocena, na ile omawiana w niniejszej pracy sprawa usytuowania podmiotu mówiącego wpływa na jego normalne funkcjonowanie, wymagałaby zapewne refleksji na temat wspomnień, sposobów ich ujmowania oraz podejmowanych wielokrotnie prób wydzielenia pamięci indywidualnej i kolektywnej. Miałyby być one kształtowane w sposób odmienny i mogłyby pozostawać we wzajemnym konflikcie, z reguły doprowadzającym do uruchomienia mechanizmów wyparcia z pamięci jednostki.

8 Twórca tego pojęcia, Langacker, charakteryzuje je jako „przestrzeń mentalną obejmującą wszystko, co mówiący i słuchający uważają za wspólne i traktują jako podstawę toczącego się między nimi w danym momencie dyskursu" (Langacker 2009: 90). Bieżąca przestrzeń dyskursu ulega aktualizacji wraz z każdą kolejną wypowiedzią. Nieco dalej dodaje Langacker: „current discourse space jest szeregiem zjawisk powiązywanych za sprawą wspólnej struktury informacji” (ibid.: 91). 


\subsection{Konstrukcja utworu - pozycja mówiącego jako obserwatora sceny}

Począwszy od pierwszych słów opowiadania, mówiący nie zataja przed odbiorcą informacji o tym, że jest jednym z bohaterów własnej wypowiedzi i opisuje sceny zakorzenione w swym doświadczeniu. Świadomie ustawia się względem nich w odmiennych pozycjach, wpływając tym samym na odbiór i postrzeganie elementów przestrzeni dyskursu przez potencjalnego adresata.

Ów brak dystansu umożliwia uznanie opowiadania za monolog wewnętrzny lub wypowiedź o zbliżonym charakterze. W ślad za Langackerem przyjąć można, że jego celem byłaby ponowna konceptualizacja, pojmowana jako „dynamiczny proces mentalny”, a także „spójna i konsekwentna koncepcja oraz podstawa opisu szeregu aspektów semantycznej i gramatycznej struktury języka" (ibid.: 52-53).

Można zauważyć, że pomimo tego, z jak niecodziennym i nieprzystającym do ludzkiej natury doświadczeniem mierzy się podmiot mówiący, jego dążenia pozostają zbliżone do tych uznawanych w myśl językoznawstwa kognitywnego za najbardziej typowe dla ludzkiego umysłu. Nastawienie na uporządkowanie przeżyć oraz wpisanie ich $\mathrm{w}$ istniejące już kategorie i schematy poznawcze, połączone $\mathrm{z}$ odniesieniem do dotychczasowej hierarchii wartości, napotyka szereg barier percepcyjnych, których zapisem jest druga część Odwiedzin, poświęcona teraźniejszości i przyszłości bohatera-narratora.

Stworzone przez Langackera pojęcia subiektyfikacji i obiektyfikacji są kontynuacją opisu optymalnego i egocentrycznego układu oglądu. W przypadku pierwszego z nich obserwator jest maksymalnie zsubiektyfikowany (skoncentrowany na obiekcie w stopniu umożliwiającym zatarcie samoświadomości), z kolei byt obserwowany jest maksymalnie zobiektyfikowany, co oznacza, że osiąga największą wyrazistość względem tła i obserwatora, a „usytuowany jest w obszarze najwyższej percepcyjnej ostrości" (Langacker 2005: 26-27).

Drugi z wariantów, częściej spotykany i łatwiejszy do osiągnięcia, prowadzi do „zatarcia dystynkcji między sceną zsubiektyfikowaną i zobiektyfikowaną wskutek zachowania świadomości SAMEGO SIEBIE przez subiekta" (ibid.: 28). Mówiący umieszcza wówczas siebie w obrębie opisywanej sceny i pozostawia odbiorcy sygnały pozwalające na wychwycenie jego obecności. We wcześniejszej sytuacji dąży raczej do oddzielenia od opisywanej sceny.

Podobnie jak niemożliwe jest zdaniem Langackera całkowite odseparowanie obserwatora od opisywanej sytuacji (ibid.: 25), trudny do osiągnięcia byłby także układ oglądu całkowicie optymalny. Można natomiast zauważyć, że możliwe jest w toku narracji wyodrębnienie kolejnych stopni subiektyfikacji, z czego bohater-narrator Odwiedzin korzysta.

Przywoływane już pierwsze zdanie opowiadania niewątpliwie akcentuje obecność mówiącego w obrębie sceny - jako jeden z maszerujących w szeregu staje się on zarazem komponentem centralnym. Kolejny akapit, zawierający deklarację 
„nie potrafię powtórzyć z tej nocy nic prócz tego, co widziałem, szeroko otwierając oczy”, wprowadza enumerację, której spoiwem jest przywołany wcześniej czasownik. W dalszej części utworu pojawi się szereg zdań wykorzystujących to powiązanie:

Widziałem więc w tę noc, jak półnagi, parujący potem człowiek [...].

Przez wiele dni potem widziałem, jak mężczyźni płakali nad kilofem, łopatą i przy lorze $[. .$.$] .$

Widziałem innych, którzy kolekcjonowali brylanty, zegarki oraz złoto [...].

Aha, widziałem także kobiety, które nosiły belki, pchały wozy i taczki [...].

Widziałem także dziewczynę (która kiedyś należała do mnie) [...].

Abstrahując od metaforycznego charakteru niektórych użyć czasownika widzieć ${ }^{9}$, zauważyć można przesunięcie na pierwszy plan samej czynności obserwowania poszczególnych zdarzeń i procesów, a co za tym idzie usytuowania mówiącego w obrębie konstruowanej sceny. Funkcję podobną do czasowników w 1. os. 1. poj. pełnią w opowiadaniu niektóre zaimki:

[...] chociaż krew z przebitego bagnetem uda obejmowała mi ciało ciepłem [...].

[...] wśród nich szła również dziewczyna, która kiedyś należała do mnie [...].

W wypowiedzi bohatera-narratora Odwiedzin zauważyć można przesunięcia w obrębie układu oglądu ${ }^{10}$ - mówiący stopniowo przenosi swoją osobę poza granicę opisywanej sceny, czyni się jej coraz mniej wyrazistym elementem. Wypowiedziami tworzącymi układ oglądu w mniejszym stopniu egocentryczny są te powiązane składniowo, choćby przez paralelizm, z każdą spośród wymienionych:

Jeszcze inny człowiek (w walce o powietrze przyduszono go w wagonie, przy szparze), leżąc w szopie na kupie dymiących ciał, kopnął nagle z całej siły schylonego nad nim złodzieja [...].

Jak dźwigali szyny, worki z cementem, betonowe słupy na ogrodzenie, jak równali pieczołowicie ziemię, głaskali szuflami ściany rowów, wznosili baraki, wieże strażnicze i krematoria. Jak zżerały ich świerzb, flegmona, tyfus i głód.

Jeszcze inni ze snobizmu starali się zabić jak najwięcej ludzi i posiąść możliwie wiele kobiet.

9 Każdemu z użyć występujących w Odwiedzinach czasowników percepcyjnych odwołujących się do zmysłu wzroku (widzieć, patrzeć, zobaczyć, spoglądać) poświęciłem uwagę w swej pracy dyplomowej, skupiając się na wykorzystaniu przez Borowskiego różnic semantycznych między poszczególnymi jednostkami.

10 Pojęcie $u k ł a d u$ oglądu jest przez Langackera (2009) tłumaczone jako usytuowanie nadawcy i odbiorcy względem omawianej sceny. Standardowy układ oglądu może zostać zaburzony w wyniku stosowania „wyrażeń użytych w funkcji innej niż sam opis”, „odniesień do wszelkiego rodzaju sytuacji wirtualnych, wyobrażonych, abstrakcyjnych lub/i wewnętrznie sprzecznych" czy wreszcie za sprawą przemieszczenia obserwatora lub innej zmiany dystansu przestrzennego rozmówców (por. ibid.: 109-111). 
Takie, które stać było na kupno kochanka - za jedwabne koszule, za złoto i za biżuterię zrabowaną ludziom umarłym.

W żadnym z wypowiedzeń obserwator nie zaznacza swojej obecności. Usytuowanie każdego z komunikatów - podrzędne względem otwierających poszczególne akapity zdań zawierających takie odniesienia - pozwala na odczytanie ich w kontekście. W konsekwencji kolejne sceny dodawane w ten sposób do kreowanego obrazu wojny uznać można za uzupełnienie zbioru doświadczeń obozowych. Po poddaniu analogicznemu podziałowi również części drugiej, rozpoczętej słowami „właśnie spoglądam przez oplecione dzikim winem okno”, wskazać można dwa fragmenty o perspektywie najmniej zorientowanej na egocentryczny układ oglądu:

Ci wszyscy zaś, którzy z powodu flegmon, świerzbu i tyfusu, a także dlatego, że byli zbyt chudzi, szli do komory gazowej, prosili pielęgniarzy (ładujących ich na krematoryjne auta), aby patrzyli i pamiętali. I aby powiedzieli prawdę o człowieku - tym, którzy jej nie zaznali.

Innych odwiedzają ci, którzy grzebiąc w zmieszanych z ziemią, przegniłych ludzkich popiołach, pilnie szukają w nich zagubionego złota.

W obu przypadkach zamykają one jedną z części utworu - pierwszą, retrospektywną, i drugą, związaną z teraźniejszością i przyszłością. Sugerowałoby to, że wbrew opiniom zawartym w dotychczasowych badaniach, m.in. D. Kuleszy, jakoby Borowskiemu „ciążyła pointa” (Kulesza 2006: 331), bardzo świadomie posługiwał się on kodą i świadomie przenosił wypowiedź na wyższy stopień ogólności w momencie zamykania refleksji.

Innym przejawem takiego zaplanowanego przenoszenia perspektywy jest scena, w której człowiek wypadający z obozowego wagonu zachłystuje się powietrzem i szepcze słowa „bracie, bracie...”. Gdy przedstawiona zostaje ona po raz pierwszy, osobą, która obejmuje owego mężczyznę, jest „inny człowiek”. Za drugim razem jest to już sam podmiot mówiący.

To samo zdarzenie opisane jest najpierw w układzie silnie zbliżonym do optymalnego, potem zaś egocentrycznego. Zabieg ten (który za pośrednictwem Stockwella i w ślad za formalistami rosyjskimi potraktować należy jako defamiliaryzacyjny) podyktowany mógł być choćby dążeniem do tym wyraźniejszego wyodrębnienia części retrospektywnej, a zarazem nadania przez bohatera-narratora sobie samemu roli widza, oglądającego projekcję własnych doświadczeń. Inną motywacją może być próba tym wyraźniejszego oddzielenia rzeczywistości wojennej i jej doświadczeń od późniejszych, już powojennych doznań mówiącego. 


\section{Wnioski}

Opowiadanie T. Borowskiego cechuje widoczna treściowa kondensacja. Przeprowadzona analiza wykazała, w jak wielu aspektach kompozycyjnych pisarz starał się o nadanie wypowiedzi określonej struktury. Przesunięcia pozycji obserwatora pozwalają na osiągnięcie pożądanego przez autora (jak zauważył przywoływany wcześniej Andrzej Mencwel (1971: 172-174)) kompromisu pomiędzy autentycznością słów naocznego świadka a uniknięciem subiektywizmu w opisie.

Nieuzasadnione wydają się dotychczasowe stwierdzenia badawcze przypisujące tekstowi Borowskiego charakter prymarnie polemiczny. Odwiedziny, co pokazała analiza usytuowania podmiotu mówiącego, są introspekcją, zaś sam bohater-narrator podejmuje próbę uporządkowania doświadczenia. Nie usuwa się przy tym z pola widzenia adresata swej wypowiedzi, egocentrycznie kreując układ oglądu wybranych scen.

Posługując się aparatem językoznawstwa kognitywnego, dostrzec można w obrębie Odwiedzin zmianę perspektyw nie tylko obserwacji, lecz także czasu. Przyszłość przedstawiona jest w utworze zupełnie inaczej z punktu widzenia ofiar obozu, tych, którzy go przetrwali, a także tych, którzy przetrwawszy, potrafili nadać sobie po zakończeniu wojny rolę inną niż wyłącznie ofiary.

Biorąc pod uwagę to, jak ujmowane są w omówionym opowiadaniu Borowskiego doświadczenia obozowe, odnaleźć można w nim słowo poświęcone pamięci i jej roli - okazuje się ona siłą zdolną sparaliżować funkcjonowanie człowieka, najpierw uniemożliwiając mu pełne zrozumienie samego siebie.

Opisane $\mathrm{w}$ artykule wielokrotne zmiany perspektywy mogą pełnić funkcję nie tylko osi organizującej kompozycję utworu (celem przekazania odbiorcy w zdarzeniu mownym obrazu obozów poukładanego już przez obserwatora), lecz także śladu prób takich działań samego bohatera. Wówczas projektowanym skutkiem jego działania byłoby odnalezienie perspektywy właściwej, pozwalającej na pełniejsze poznanie. Ten specyficznie kognitywny charakter narracji czyni Odwiedziny tekstem produktywnym interpretacyjnie.

Dalsze analizy utworu (oraz innych krótkich form tworzących Kamienny świat) mogłyby z pewnością przynieść kolejne spostrzeżenia dotyczące właśnie pozycji ofiary lub miejsca negatywnych doświadczeń w pamięci oraz sposobów ich przyswajania, porządkowania i późniejszego przywoływania przez umysł człowieka. 


\section{Literatura}

Borowski T., 1997, Odwiedziny, [w:] idem, Utwory wybrane, oprac. A. Werner, „Biblioteka Narodowa", I 276, Wrocław, s. 80-81.

Borowski T., 2001, Niedyskrecje pocztowe. Korespondencja Tadeusza Borowskiego, zebrał i oprac. T. Drewnowski, Warszawa.

BuryŁa S., 2004, Wstęp, [w:] T. Borowski, Proza, t. 1, oprac. S. Buryła, Kraków, s. 6-19.

Drewnowski T., 1992, Ucieczka z kamiennego świata. O Tadeuszu Borowskim, Warszawa.

Kulesza D., 2006, Dwie prawdy. Zofia Kossak i Tadeusz Borowski wobec obrazu wojny w polskiej prozie lat 1944-1948, Białystok.

LANGACKER R.W., 2005, Obserwacje i rozważania na temat zjawiska subiektyfikacji, tłum. M. Majewska, Kraków.

LANGACKeR R.W., 2009, Gramatyka kognitywna. Wprowadzenie, tłum. E. Tabakowska i in., Kraków.

Mencwel A., 1971, Borowski albo dramat absolutyzmu moralnego, [w:] idem, Sprawa sensu. Szkice, Warszawa, s. 150-185.

Stockwell P., 2006, Poetyka kognitywna. Wprowadzenie, red. nauk. E. Tabakowska, tłum. A. Skucińska, Kraków.

ToKARSKi R., 2004, Semantyka barw we współczesnej polszczyźnie, Lublin.

Werner A., 1971, Zwyczajna apokalipsa. Tadeusz Borowski i jego wizja świata obozów, Warszawa.

Werner A., 1997, Wstęp, [w:] T. Borowski, Utwory wybrane, oprac. A. Werner, „Biblioteka Narodowa”, I 276, Wrocław, s. I-CLIII.

\section{The Observer and His Position in Tadeusz Borowski's Short Story Odwiedziny ('The Visit') Summary}

The article is an analysis of Tadeusz Borowski's short story Odwiedziny ('The visit'). It focuses on linguistic and narrative devices through which the speaker influences the recipient's perception, and so shapes the reading of his work. The first part is introductory, it presents the goals of the paper. The next part recalls the most important existing interpretations, both of Borowski's literary output as a whole, and of the text at hand. They form the starting point to an analysis of the position of the character-narrator with regard to the events he is describing, and to the relation between the author, the narrator, and the main character of the story. These considerations constitute the third part of the present paper. It begins with a citation of the full text of the story, and is followed by the main argument announced in the title which refers to Ronald Langacker's cognitive grammar and takes into special consideration such notions as scene, current discourse space, and vantage point. The closing part of the paper contains conclusions, contrasted with the theses put forward in the context of Borowski's work, as well as suggestions of possible directions of further analysis of the story within the framework of cognitive linguistics. 